\title{
Reviewing MGNREGA: The Cheering Method of Poverty Reduction
}

\section{Muzafar $\mathrm{AM}^{1 *}$ and Jahangir $\mathrm{AB}^{2}$}

${ }^{1}$ Depertment of Economics, Barkatullah University, Madhya Pradesh, India

${ }^{2}$ Department of Economics, Maulana Azad National Institute of Technology, Madhya Pradesh, India

*Corresponding author: Muzafar AM, Department of Economics, Barkatullah University, Bhopal, Madhya Pradesh, India, Tel: +91-8236097817; E-mail: inhaqmuzafar@gmail.com

Received date: April 14, 2017, Accepted date: April 28, 2017, Published date: May 05, 2017

Copyright: ( 2017 Muzafar AM et al. This is an open-access article distributed under the terms of the Creative Commons Attribution License, which permits unrestricted use, distribution, and reproduction in any medium, provided the original author and source are credited.

\begin{abstract}
It is hard to think development of a nation without the development of rural economy, neglecting of rural means neglecting of overall development. The real development of India lies in the economic betterment of rural people for which government needs to make strong economic policies and better implementing strategies. MGNREGA is the scheme with lot of alacrity, zeal and potential to boost economy and social transformation of lives at large. Further MGNREGA acts as an engine to achieve the goal of inclusive growth where sustainable developmental parameters are the yardstick to measure development. In this paper we have analysed the Indian perspective of rural development, joblessness of poor, and the socio-economic conditions of rural people through reviewing of previous work. Furthermore, in this paper it is also explained how MGNREGA can be made a cheering scheme and more effective. At last some important suggestions have been proposed to make this scheme more powerful, fruitful and valuable.
\end{abstract}

Keywords:

Social development; Economic development; MGNREGA; Rural upliftment; Rural employment

\section{Introduction}

Fundamentally India is an agro-based country with most of its population lives in rural areas, the development of India holistically rely more on upliftment of rural India, as majority of the population (around 70\%) living in about 600,000 small villages mostly depends upon the agriculture and small scale informal-industries [1]. In India, rural people are in pervasive conditions of chronic and hardships. Homeless in India have been a problem for centuries mostly found in rural areas than urban, which are characterized by landless, suffering from malnutrition, low income, and abject poverty. The development of these 700-million strong rural population has become a matter of concern for the state as well as for the central government. As India's most of the population resides in villages and their social justice, upliftment, and economic development is the key component for the overall development of the nation [2]. Development of nation cannot be achieved without the development of rural India and real fruits of inclusive development cannot be achieved unless the nation is not freed from the clutches. Further, the crime rate, Farmer suicide, starvation deaths, labour exploitation and caste humiliations in rural areas are growing prolifically. To mitigate such problems government intervention is must which can be achieved through better developmental initiatives and best employment opportunities to reduce poverty and increase the standard of living [3].

\section{Referring M.K Gandhi " The future of India lies in its villages”}

Social security and poverty alleviation has remained a main goal of India since its ages, when we go through history the early rulers were also working towards the welfare of the people like Kautilya in his Arthashasthra mentioned 'welfare of people lies in the welfare of king states as a testimony that progress of people was the real development of state. So has Mughal's contributed for this nation during the medieval age welfare of people and infrastructure development was the prime concerns of every king during the tenure. Unfortunately, India has gone through an adverse stage of development during British rule where humans were treated as machines for the sake of personal growth of rulers and every kind of obstruction was put up to hinder the poverty reduction.

However, the independent India has taken this issue of poverty reduction and human development seriously and has come up with many social security and welfare schemes for the people, where main concerns of government were human resources have to be transformed into an asset instead of a liability. Since the government came up with many schemes aiming to promote equitable and sustainable human development responsive to unmet needs of poor. These schemes have a powerful impact on the rural life of poor and have been launched to reduce poverty and accelerate sustainable development. But none of the schemes, in reality, have completely solved the problem of poor. India continues to be poor after 67 years of independence [4]. Census 2011 revealed that there are 1.77 million people homeless in India [5]. More than 20 percent of the Indians in the age group of 15 to 25 are jobless and seeking work and completely fail to get work; the growth in jobs have not kept pace with the rising number of aspirants, resulted in unemployment at a higher rate despite India supposedly being one of the brighter spots in a growing global economy [6].

Despite the govt efforts to mitigate the problems, nothing is really working. The government of India needs to grant more and more funds with innovative strategies to encourage and motivate state governments to plan and implement to achieve specific goals. However, MGNREGA is the promising initiative which is based on the Gandhian ideology of achieving development through village economy 
and decentralisation of authority to self-governing communities to boost their life.

\section{About MGNREGA}

Every nation wants to optimize its resources and trigger its growth through development programs and inclusive strategies. India is the one, which needs these development programs more than any other nation, as $1 / 3$ of world's poor population lives in India and the government has been always trying to meet the needs of underprivileged through its development schemes and desires better outcome. India at a very challenging stage, when it was imperative to have a systematic plan and strategy to optimize its resources and trigger its growth and employment opportunities has introduced MGREGA, which is one of the best and well-recognized schemes of central government, it is not famous in India only but also throughout the world. The introduction of MGNREGA was the beginning of the golden period in the lives of rural people with an aim to achieve progress and prosperity. It is a great step towards the realization of rural transformation and aims at arresting migration and poverty. It has enhanced people's livelihood by developing infrastructure and local jobs for rural development.

It is believed that MGNREGA has potential to transform the lives of rural people and the infrastructure of rural areas. World Bank in its report in the year 2012 declares MGNREGA largest employment alleviation scheme and many African countries have taken MGNREGA as a model to reduce poverty in their respective countries. The MGNREGA is not mere a scheme but an act since 2005, in order to eradicate poverty and unemployment by offerings jobs to the people living in the rural areas. The act gives planning right to every individual at gram (village) level and the participative right to every sect whether General, Sc, St, Men or Women of the society. Its implementation stage is multi-tire starting from the centre, state, district levels and ends with village level. MGNREGA is the act with the aim of high objectives of inclusive growth and to make it reachable to every village so that people could derive various benefits like employment, economic and social infrastructure facilities. Even though MGNREGA is the best policy for poverty reduction and employment generation but its current status is a matter of concern. Despite having such a scheme India still have low human development indices ranks 130th among 188 countries and 66rd out of 88 in the world hunger index (UNDP, 2016). Poverty reduction is the main component of this scheme but nothing good has been reported yet, even its completion of twelve years.

\section{Literature Review}

Certainly, MGNREGA is a unique and one of the best policies of central government to reduce poverty and unique way participation in decision making about work and work management. But at the same time, there are some loopholes in its implementations, the work done trough NREGA is believed to be substandard. The best way to boost its proper working is to find the problems associated with the scheme and its implementation further, come with the innovative techniques to solve those problems that could be observed through findings of previous studies. The below literature gives the brief view about the scheme and will help in recognising the strengths and weakness of the scheme (MGNREGA).

Ghosh [7], studied on Employment Growth: The Latest Trends. Reveals that the problem with MGNREGA is in its implementation.
This could be resolved by keeping the proper vigil on implementing authority, so that the benefit could reach to the underprivileged. Further, suggested that MGNREGA could prove better only if implemented properly and perceived ethically.

Centre for Budget and Governance accountability [CBGA] [8], in the study about NREGA observed the awareness level of people and payment of wages among three states namely AP, MP, and Chhattisgarh of India. It was reported that among the 3 states the highest level of awareness was in Andhra Pradesh (97.5\%) followed by Chhattisgarh (69\%) and MP (45\%). Few issues were also raised by the people regarding workload, nonpayment of wages.

Poorest Area Civil Society (PACS) [9], considered the awareness level among poor people after the implementation of the scheme in Bihar which was found low due to unawareness. It was recommended that awareness program must be organised in states to spread awareness about the scheme and its provisions so that people can be benefitted in large content.

Khan and Salluja [10], made a study of local village with a population of 400 households around 2500 people who mainly depend on agriculture to examine the impact of MGNREGA on employment generations. In this study, production activities of local people and income and expenditure levels were recorded. This study revealed that most of the people were not aware of the scheme and there is a need of proactive role from the Gram panchayat's to spread awareness among the public so that they could benefit from the program for which it has been introduced.

Dreze [11], examined the extent of corruption in MGNREGA in Orissa. In his study it was revealed that workers were earning the wages of Rs 70/day and payments were being made within a fortnight. There is a great opportunity for the rural people to get benefit from this scheme. Not only this, the people were appreciating a lot about the scheme and believe that it will help them a lot in avoiding migration.

Govt of India [12], comptroller and Auditor general of India (CAG) report emphasized on "Significant deficiencies and their impact on MGNREGA implementation" The report find out that many deficiencies were found by the Govt. in implementation case mainly lack quality and competent persons at Gram panchayat levels. It was also found that poor planning, no transparency made it difficult to check the progress of the scheme. Apart from this many problems like financial accountability, evaluation, audit, misutilization of resources were also reported.

Jaswal and Mistry [13], made a study on "Will MGNREGA Ensure Security against Hunger" in Rajasthan which highlights various problems associated with MGNREGA. Many problems were found like job cards which were issued were without photographs, lack of proper information about the scheme, delay in the application process. It was also found that average period of employment was 39 days. When comparisons were made among the districts regarding employment generation it was found that only two districts were there with namely Dungerpur and Udaypur with 63 and 67 days of work which was better in comparison to other districts. When wages were considered, it was found that average wages paid to labours were less than even agricultural wages in many areas and also delay in payments.

Planning Commission, analyzed 200 backward districts which reveal that in some districts authorities (Gram panchayat \& Gram Sabha) are sleeping, non-functional and even does not exist. CAG also revealed that it has got deteriorated because an exact number of 
workers are not getting a job and also was found that in the year 2007 (April to December) an actual number of beneficiaries even dropped by $3.3 \%$ of total job seekers. It was also found that the workers were not getting wages in entirety.

National Federation of Indian Women [MORD] [14], studied to what extent women have got benefitted from the program and their concern towards the program. This study was conducted in 4 districts of Chhattisgarh and was found that women working in MGNREGA were very happy with the scheme and regular payments of wages being provided. But some people were unaware of the schemes who were mainly SC, ST and illiterate. Apart from this, some problems were reported like lack of safe drinking, first aid facility etc.

Jacob [15], Impact of MGNREGA on migration he examined the role of MGNREGA in migration in Tamil Nadu. He observed that before MGNREGA there used to be more migration of people from the state around 400, but after implementation of program it got halved within 2 years of implementation of the scheme.

Institute of Applied Manpower, Delhi, submitted a report on "All India evaluation of MGNREGA". In this report the sample size of 20 districts (Northern, Western, Southern, north east region of India) and 300 beneficiaries from each district. When a survey was conducted among the beneficiaries and questions were put to them, in response it was found labourers working in MGNREGA were not given job cards and those who were having cards were without photos affixing thereof. It revealed that some persons were paying money towards the officials for getting job cards. It was also revealed that they were not getting sufficient days of work and only some people could work for more than 35 days of work. The reason for not getting 100 days of work was that scheme was started late.

Mathur [16], explained the issues related with MGNREGA like authorities who have issued job cards in favour of labours were totally incomplete, inner pages were not there on which work done is being recorded. The workers were not getting wages for the services rendered by them.

Khera and Nayak [17], emphasised on "Women Participation in MGNREGA. They analysed that MGNREGA can improve the standard of living, earning capacity, economic development of women when compared with men i.e., they can develop at par with men. This study was also conducted to know how much percentage of women is working in MGNREGA. It was found that there were many variations among the women participate in MGNREGA when samples were collected. Apart from this many issues were raised by women like lack of crèche (day centers) for their children and contractors were there who were offering the job to labourers were working on an illegal basis.

Dey and Bedi [18], study on the National Rural Employment Guarantee Scheme in Birbhum. In this study, many questions were posed to the respondents. It was analysed that they are not getting job throughout the season and there is a delay in the payments due to which less no. of workers now prefer this scheme. Most important thing about the study is that records were maintained properly. This study reveals that if the program has to prove fruitful then it has to create more job days in all seasons and timely payment of wages should be provided.

Dreze and Oldiges [19], made a study of MGNREGA's contribution between years 2006-2008. It was found that MGNREGA has generated 90 crores person-days of employment in 2006-2007 at a cost of 900 crores. It was also found that there are many difficulties in employment generation in different states. There are some states in which program have not yet been launched. It was also reported that Rajasthan was founded as the best performer among all states in terms of employment generation.

Dutta et al. [20], analysed that there are so many problems which rural people of this country are suffering from. MGNREGA can be noteworthy for removing these problems if implemented according to the intended purpose. There are rural people who are vulnerable to risks which can also be eradicated through MGNREGA.

Dey [21], examined the study of 4 states (Gujarat, MP, Maharashtra, Rajasthan) to know the awareness level among rural people about MGNREGA. After conducting the study it was found that many people were not aware of the scheme because of the low level of education.

\section{Discussion}

MGNREGA as an important act in the history of India has brought the happiness in the lives of poor and enhanced their livelihood in many ways:

$M G N R E G A$ has proven effective in various ways like employment generation, rural infrastructure, equal participation and poverty reduction.

MGNREGA has provided jobs locally and increased the standard of living in rural areas more especially women got easy access to work at equal wage rate.

MGNREGA has reduced migration to the greatest extent and encouraged reverse pull migration, which made the life of poor easy as they are able to earn better.

MGNREGA has brought a number of serious environmental issues such as air pollution, water pollution, soil degradation, and desertification in control and has reduced starvation and malnutrition.

MGNREGA boosts sustainable development and ensures inclusive development with a special inclination to develop land and water more especially concentrating more on human labour than a machine which has reduced risk at large.

MGNREGA is an act rather than a simple scheme, which has strengthened Gram Sabhas, policy implementation, and reduced corruption.

\section{Despite the greatness of scheme it is subject to many criticisms}

Many studies proved that resources are being misused through MGNREGA, increased the level of corruption and favouritism in job offerings.

The rural people still don't have the complete awareness about many aspects of the Act like job cards, resource utilization, women participation, wage rate and bank accounts.

Disbursements of funds are not comprehensive and clear further, Delayed payments; Low wages, wastage of funds have remained serious issues.

Job card mismanagement, fake bank accounts, and social auditing are the critical concerns related to the scheme.

Frequently complaints like no 100 days guaranteed work, and delay in issue of job cards, work delay, preferential work sites, and poor work are being found. 
Citation: Muzafar AM, Jahangir AB (2017) Reviewing MGNREGA: The Cheering Method of Poverty Reduction. J Glob Econ 5: 250. doi:

Page 4 of 4

\section{Conclusion}

MGNREGA has brought a bit of smile on the faces of poor people who once used to walk with their heads down are now walking around with their heads raising and has totally changed their lifestyle. Further, if the scheme has to prove effective there must be a proper authority, responsibility, and accountability. Implementing authority must be realized the importance of scheme and welfare of poor people. Most important officials should not get indulge in corruption and favouritism.

\section{References}

1. Planning commission (2012) Government of India.

2. Bhat JA, Yadav P (2015) MG-NREGA:A Pathway for achieving Sustainable Development. International Journal of Engineering Technology, Management and Applied Sciences 3: 339-347.

3. Desai A (2003) A Study of Rural Economics. Himalaya Publishing House, India.

4. Kaur R (2013) Why India is still a poor country.

5. Ministry of Home Affairs (2011) Office of the Registrar General \& Census Commissioner, India, Government of India.

6. Arun MG (2016) Where are the jobs. Why is an economy apparently on the upswing not being able to generate enough new jobs

7. Ghosh J (2006) Employment Growth: The latest trends.
8. CBGA (2006).

9. Samarthan-Center for Development Support, with support from Poorest Area Civil Society (PACS) Program, Status of MGNREGA Implementation.

10. Impact of Mgnrega on Rural Livelihoods (2007) 10thSustainable Development Conference on Sustainable Solutions: A Spotlight on South Asian Research, Pakistan.

11. Dreze J (2007) Mgnrega: Dismantling the contractor raj. The Hindu.

12. Government of India (2007) Report on Mgnrega.

13. Jaswal A, Mistry P (2007) Will Mgnrega Ensure Security Against Hunger.

14. A study on Mgnrega (2008) Study by Nation Federation of Indian Women (NFIW) for MORD.

15. Jacob N (2008) The Impact of Mgnrega on Rural Urban Migration: Field survey of Villapuram district Tamil Nadu.

16. Mathur L (2009) Silent but successful initiative, The Hindu.

17. Khera R, Nayak N (2009) Empowerment Guarantee Act. Economic and political weekly 44: 49-57.

18. Dey S, Bedi A (2010) The National Rural Employment Guarantee Scheme in Birbhum. Economic and Political Weekly 41: 19-25

19. Dreze J, Oldiges C (2011) Employment Guarantee: The official picture. Oxford University Press, New Delhi.

20. Dutta P, Murgai R, Ravallion M, Dominique WV (2012) Does India's Employment Guarantee Scheme Guarantee Employment. World Bank.

21. Dey M (2014) Implementation of Mgnrega: A Study of Two Gram Panchayats in Jhalawar, Rajasthan. Urbanization in Asia. 